\title{
BioéthiqueOnline
}

\section{When Disability Rhymes with Negative Bias: A Response to Verpaelst}

\section{Susan E. Roush}

Volume 4, 2015

Reçu : 28 Apr 2015; publié : 25 Jun 2015; éditrices : Maude Laliberté \& Aliya Affdal; travail créatif discuté : F Verpaelst. Disability is in the Eye of the Beholder BioéthiqueOnline 2015, 4/8

URI : https://id.erudit.org/iderudit/1035501ar

DOI : https://doi.org/10.7202/1035501ar

Aller au sommaire du numéro

Éditeur(s)

BioéthiqueOnline

ISSN

1923-2799 (numérique)

Découvrir la revue

Citer cet article

Roush, S. E. (2015). When Disability Rhymes with Negative Bias: A Response to Verpaelst. BioéthiqueOnline, 4. https://doi.org/10.7202/1035501ar
Résumé de l'article

Dans ce commentaire, sur le texte de F. Verpaelst « Disability is in the Eye of the Beholder ", je discute du pouvoir du langage et des images dans l'élaboration de notre construction sociale de la vision du monde et de la vie avec un handicap. La notion de handicap implique souvent un biais négatif, plutôt qu'une valorisation de la dignité personnelle. 


\title{
When Disability Rhymes with Negative Bias: A Response to Verpaelst
}

\author{
COMMENTAIRE / COMMENTARY \\ Susan E. Roush ${ }^{1}$
}

Reçu/Received: 28 Apr 2015

Publié/Published: 25 Jun 2015

Éditrices/Editors: Maude Laliberté \& Aliya Affdal

Travail créatif discuté/Creative Work discussed: F Verpaelst. Disability is in the Eye of the Beholder BioéthiqueOnline 2015, $4 / 8$

2015 SE Roush, Creative Commons Attribution 4.0 International License

\section{Résumé}

Dans ce commentaire, sur le texte de F. Verpaelst "Disability is in the Eye of the Beholder », je discute du pouvoir du langage et des images dans l'élaboration de notre construction sociale de la vision du monde et de la vie avec un handicap. La notion de handicap implique souvent un biais négatif, plutôt qu'une valorisation de la dignité personnelle.

Mots clés

handicap, dignité, biais négatif, construction sociale, vision du monde

\section{Summary}

In this commentary on F. Verpaelst's text "Disability is in the Eye of the Beholder", I discuss the power of language and image in shaping our constructed view of life with disability. Disability often rhymes with negative bias, rather than empowering personal dignity.

\section{Keywords}

disability, dignity, negative bias, social construction, view of life

\section{Affiliations des auteurs / Author Affiliations}

${ }^{1}$ Professor, Physical Therapy Department, University of Rhode Island, USA

\section{Correspondance / Correspondence}

Susan E. Roush, roush@uri.edu

\section{Conflit d'intérêts}

Aucun déclaré
Conflicts of Interest

None declared

Wow - I would love to meet you, Mr. Verpaelst! I enjoyed your paper [1] and the imaginative and genuine way you presented your ideas. And, they are great ideas! I don't like the word 'disability' either, but it is probably better than 'handicapped' which evokes for many the myth of a person with "cap-in-hand" seeking handouts [2]. The latter, for me, conjures up visions of Jerry Lewis telethons and the presence of those demeaned, pitiful "Jerry's Kids." The recent announcement of the demise of this telethon [3] leaves the world a better place for all of us, not just for those who supposedly benefit from this type of fundraising. Maybe our culture is starting to catch up with you, Mr. Verpaelst, recognizing that this beneficence is intertwined with a high cost to personal dignity. Why is it so easy to believe that a person with a disability is helpless and pitiful? Psychologist Beatrice Wright wrote about this assumption that equates a disability with a sad, angry, miserable life and called it the Fundamental Negative Bias [4], and later wrote, "We must again remind ourselves how seriously mistaken outsiders can be when led astray and deluded by the compelling nature of their own values and perspectives." [5] When did she do this work? Over 50 and 30 years ago, respectively! How can we still be grappling with these basic human considerations for people whom others view as different? Where is the paradigm shift? Unfortunately, the stereotypes about people with disabilities are powerful and deeply rooted, and that is why your voice is so important.

Yes, disability is in the eye of the beholder, and I think consideration of our language can be part of helping society and individuals see people and not disabilities. I will close with an example of how inaccurate language can be and how it perpetuates stereotypes. Before sitting down to writing this, I spent a little time on the Web to learn more about you and your work as a disability advocate. 
Somewhere I read that you "... suffered from dwarfism...," which could conjure up a vision of you as one of "Jerry's kids." I, however, both cringed at the word and chuckled because after reading your paper I knew that you do not "suffer" from anything, and certainly not because you have dwarfism. Please keep your voice strong! Thank you for opportunity to comment on your good work.

\section{List of References}

1. Verpaelst, F. 2015. Disability is in the Eye of the Beholder BioéthiqueOnline, 4/8

2. Langtree, I. 2011. Disability or disabled - which term is right? Disabled World: Disability News \& Information.

3. Oldenburg, A. 2015. MDA ends Jerry Lewis Labor Day telethon. USA Today, May 1.

4. Wright, B. 1960. Physical Disability: A Psychological Approach, New York: Harper \& Row.

5. Wright, B. 1983. Physical Disability: A Psychological Approach, $2^{\text {nd }}$ Ed., New York: Harper \& Row. 